\title{
Crop Residue Considerations for Sustainable Bioenergy Feedstock Supplies
}

\author{
Douglas L. Karlen • Jane M. F. Johnson
}

Published online: 7 February 2014

(C) Springer Science+Business Media New York (outside the USA) 2014

\begin{abstract}
The anticipated 2014 launch of three full-scale corn stover bioenergy conversion facilities is a strong US market signal that cellulosic feedstock supplies must increase dramatically to supply the required biomass in a sustainable manner. This overview highlights research conducted by the USDAAgricultural Research Service Renewable Energy Assessment Project (now known as the Resilient Economic Agricultural Practices) team as part of the National Institute for Food and Agriculture Sun Grant Regional Feedstock Partnership Corn Stover team. Stover and grain yield, soil organic carbon, soil aggregation, greenhouse gas, energy content of the stover, and several other factors affecting the fledgling bioenergy industry are addressed in this special issue of the journal.
\end{abstract}

Keywords Corn stover - Wheat straw - Soil organic carbon · Aggregation · Microbial community · Feedstock quality · Simulation modeling

This issue of BioEnergy Research is the first of two special issues summarizing research conducted as part of the National Institute for Food and Agriculture (NIFA) Sun Grant Regional Feedstock Partnership. It focuses on projects led by USDAAgricultural Research Service (ARS) scientists and engineers associated with the Renewable Energy Assessment Project (REAP) in cooperation with several university partners, and engineers from the US Department of Energy (DOE) Idaho National Laboratory (INL). The focus for this issue is on corn

D. L. Karlen $(\bowtie)$

USDA-Agricultural Research Service (ARS), National Laboratory for Agriculture and the Environment (NLAE), 2110 University Boulevard, Ames, IA 50011, USA

e-mail: Doug.Karlen@ars.usda.gov

J. M. F. Johnson

USDA-ARS-North Central Soil Conservation Research Laboratory

(NCSCRL), Morris, MN 56267, USA
(Zea mays L.) stover and cereal [primarily wheat (Triticum aestivum L.)] residues because they are the two potential lignocellulosic feedstock materials grown on the largest area in the USA.

The anticipated 2014 launch of three full-scale corn stover bioenergy conversion facilities is a strong market signal in the USA that cellulosic feedstock supplies must increase dramatically to supply 242 million $\mathrm{Mg}_{\text {year }}{ }^{-1}$ for each facility producing biofuel at $252 \mathrm{~L} \mathrm{Mg}^{-1}$. Field research designed to sustainably provide agricultural biomass for bioenergy production in the USA can be traced back to the 1970's oil crisis, although at that time the focus was primarily on soil erosion concerns. The information summarized in this issue covers a much broader range of environmental issues (e.g., soil organic carbon (SOC), greenhouse gas (GHG) emissions, microbial communities, cover crops, etc.) using data collected primarily from studies conducted since 2005, when the DOE and USDA jointly released the Billion Ton Study (BTS) [1]. The 2005, BTS made a reasonable attempt to balance the need for crop residues to protect soil resources from wind and water erosion, while still establishing their potential as a sustainable feedstock available to support a viable biofuel industry, thus justifying substantial investment by private sector and government entities in emerging technologies and facilities. However, ARS scientists were concerned that managing biomass harvest with only an erosion control focus was inadequate to address other crop and soil productively issues, including SOC [2]. Therefore, a multilocation ARS-REAP team was formed to address the broader issues of soil quality degradation and more specifically the SOC balance. The SOC and GHG concerns were quickly recognized by the DOE as BTS deficiencies. Therefore, working through the "Office of Biomass Products" (now known as the Biomass Energy Technology Office), the DOE established a Regional Feedstock Partnership research program through the NIFA Sun Grant Association to address those needs. This team coordinated their 
efforts leveraging new experiments with several ongoing and long-term experiments conducted by USDA-ARS and their university partners. This special issue highlights the research results of this cross-institutional team.

Karlen et al. [3] establishes the scope of this multilocation project by summarizing corn grain and stover yields representing 239 site-years of data collected from 36 research sites, as well as the additional N-P-K removed by harvesting an average of 3.9 or $7.2 \mathrm{Mg} \mathrm{ha}^{-1}$ of stover from 28 of those sites. Birrell et al. [4] then examines the impact of various stover harvest management strategies by reporting on a 4-year case study project conducted in cooperation with POET-DSM near Emmetsburg, IA, USA one of the three sites where commercial cellulosic ethanol production will commence in 2014. Huggins et al. [5] provided yield and nutrient removal information for cereal straws in the Pacific Northwest by summarizing conventional and no-tillage studies conducted with and without residue harvest. They conclude that substantial tradeoffs must be evaluated on a site-specific basis before making any final decision regarding sustainable harvest of crop residues for any purpose. Bonner et al. [6] further emphasize the importance of subfield management by using the Landscape Environmental Assessment Framework (LEAF) simulation model to show how five USA Corn Belt states (Nebraska, Iowa, Illinois, Indiana, and Minnesota) could use no-tillage, cover crops, and vegetative conservation barriers throughout agricultural landscapes to provide between 148 and 194 million $\mathrm{Mg}$ year $^{-1}$ of corn stover without negatively affecting soil resources. Section 1 concludes with an economic case study by Archer et al. [7] that uses a portion of the Regional Partnership data to show that breakeven field-edge biomass prices range from $\$ 26$ to $\$ 42 \mathrm{Mg}^{-1}$ in Iowa and from $\$ 54$ to $\$ 73 \mathrm{Mg}^{-1}$ in North Dakota.

Section 2 examines soil responses to crop residue harvest at several partnership locations. Johnson et al. [8] uses the current studies as well as an extensive literature base to approximate the minimum amount of crop residue that needs to be returned to sustain SOC levels. Their results emphasize the extreme variability associated with different soils, weather patterns, and crop growth conditions by showing that the estimated average minimum residue return rate for 35 studies was $6.38 \pm 2.19 \mathrm{Mg}$ stover $\mathrm{ha}^{-1}$ year $^{-1}$. The most important point of this article, however, is that it refutes any notion that a universal minimum residue requirement exists, reinforcing the need for field, or better yet, subfield management decisions. Osborne et al. [9] continue quantifying SOC effects by examining the impact of stover harvest on soil aggregation and particulate organic matter. Using Regional Partnership data from three research sites (Brookings, SD, USA; Morris, MN, USA; and Ithaca, NE, USA), they show that for these western Corn Belt locations, soil aggregate distribution was negatively impacted unless another carbon source, such as cover crop residue, was added. Quantitatively, this soil physical property change was confirmed by lower amounts of soil organic matter (SOM), fine particulate organic matter (fPOM), and total particulate organic matter (tPOM) when crop residues were harvested. Benjamin and Karlen [10] continued with assessments of crop residue harvest on the least limiting water range (LLWR) as an indicator of soil compaction effects. They showed that soil physical properties were degraded by loss of SOM due to tillage and possibly erosion, and therefore concluded that crop residue removal rates be limited to levels that maintain or even increase SOM levels. Lehman et al. [11] completed the soil response section by examining crop residue harvest impacts on the soil microbial community. Using fatty acid and DNA analyses for soils from four Partnership locations (Brookings, SD, USA; Florence, SC, USA; Ithaca, NE, USA; and Morris, MN, USA) with contrasting soil climatic conditions and substantial differences in $\mathrm{SOM}$ and $\mathrm{pH}$, they showed that high $\left(\sim 7.2 \mathrm{Mg} \mathrm{ha}^{-1}\right.$ year $\left.^{-1}\right)$ stover harvest rates tended to reduce the fungal:bacterial ratio. This response was consistent with decreased aggregate stability and an increase in the erodible fraction discussed by Osborne et al. [9].

Section 3 examines GHG responses to stover harvest treatments. Jin et al. [12] summarizes static chamber estimates of GHG emissions from nine corn production systems under various crop residue and tillage management practices across the USA Corn Belt. They found that stover harvest generally decreased total soil $\mathrm{CO}_{2}$ and $\mathrm{N}_{2} \mathrm{O}$ emissions by -4 and $-7 \%$, respectively, when compared to no stover removal. Decreased emissions were attributed to less stover $\mathrm{C}$ and $\mathrm{N}$ inputs and possible microclimate differences due to changes in soil cover. Baker et al. [13] added to the GHG knowledge base by summarizing automated continuous chamber $\mathrm{CO}_{2}$ and $\mathrm{N}_{2} \mathrm{O}$ flux data collected between spring 2010 and spring 2012 for three levels of stover harvest: none, full, and intermediate. They show no significant difference in $\mathrm{N}_{2} \mathrm{O}$ emission as a function of stover harvest, but $\mathrm{CO}_{2}$ loss from the full removal plots was slightly lower than from the zero removal plots. However, the emission difference between the two treatments was much smaller than the amount of $\mathrm{C}$ removed with the stover. This implies that $\mathrm{C}$ was being lost from the full removal plots - a phenomenon confirmed by rigorous soil sampling. Campbell et al. [14] complete this section by using data collected at corn stover Regional Partnership sites to test performance of the DAYCENT simulation model for predicting impacts of stover harvest. Overall, the model performed well for simulating SOC changes and stover yields, reasonably well for predicting grain yields, but highly variable with regard to simulating $\mathrm{N}_{2} \mathrm{O}$ emissions.

The final section examines corn stover feedstock quality and energy yields. Mourtzinis et al. [15] quantified lignin and structural carbohydrate concentrations in samples from two ARS-REAP research sites. Precipitation and temperature patterns were highly correlated with stover composition indicating that in addition to their effect on biomass yield, weather 
patterns may have multiple effects on potential biofuel production. Cantrell et al. [16] provides a final insight regarding the use of corn stover for bioenergy by quantifying gross energy distribution within various plant fractions. Based on 4 years of research, they conclude that harvesting 25 to $100 \%$ of the above-ground biomass could supply between 30 and $168 \mathrm{GJ} \mathrm{ha}^{-1}$ depending upon annual rainfall. At the highest yield, this feedstock could therefore support a $500 \mathrm{MW}$ power plant with a stover collection radius of $32 \mathrm{~km}$.

Overall, the REAP team has been highly successful in providing crucial information needed to help establish the fledgling bioenergy industry in the USA Fiscal resources provided by the DOE have been highly leveraged by a very dedicated group of ARS scientists and their university partners. As stated by a 2013 DOE review team, "this project provided a broad assessment of stover yield potential, feedstock characteristics and sustainability metrics. LEAF provides an analytical framework to explore the balance between economic drivers and sustainability constraints. Development of the database for further meta-analyses by team members is noteworthy. Additional research is needed to quantify effects of cover crops, perennial segments within extended rotations, as well as proper utilization of animal manures. Future work should specifically address development of the best management practices for biomass harvest, while also improving soil and water quality relative to conventional production practices." These recommendations are being pursued by rebranding the ARS-REAP as the "Resilient Economic Agricultural Practices" team and developing investment opportunities for industry, nonprofit, government agency, and other partners interested in support multilocation research such as this through the Agricultural Technology Innovation Partnership (ATIP) Foundation.

We wish to thank all of the authors, editors, reviewers and especially the research support personnel who have made it possible to accomplish the work represented by the 14 articles in this special issue. Finally, we dedicate this special issue to the late Dr. Wally Wilhelm (USDA-ARS) for his foresight and dedication to safeguarding the soil resource for meeting society's demands now and for future generations.

\section{References}

1. Perlack RD, Wright LL, Turhollow A, Graham RL, Stokes B, Erbach DC (2005) Biomass as feedstock for a bioenergy and bioproducts Industry: The technical feasibility of a billion-ton annual supply. US Department of Energy and US Department of Agriculture. http:// www.eere.energy.gov/biomass/pdfs/final_billionton_vision_report2. pdf. Accessed 28 Aug 2013

2. Wilhelm WW, Johnson JMF, Hatfield JL, Voorhees WB, Linden DR (2004) Crop and soil productivity response to corn residue removal: a literature review. Agron J 96:1-17

3. Karlen DL, Birrell SJ, Johnson JMF, Osborne SL, Schumacher TE, Varvel GE, Ferguson RB, Novak JM, Fredrick JR, Baker JM, Lamb JA, Adler PR, Roth GR, Nafziger ED (2014) Multi-location corn stover harvest effects on crop yields and nutrient removal. Bioenergy Res 7(2). doi:10.1007/s12155-014-9419-7

4. Birrell SJ, Karlen DL, Wirt A (2014) Development of sustainable corn stover harvest strategies for cellulosic ethanol production. Bioenergy Res 7(2). doi:10.1007/s12155-014-9418-8

5. Huggins DR, Kruger CE, Painter KM, Uberuaga DP (2014) Sitespecific trade-offs of harvesting cereal residues as biofuels feedstocks. Bioenergy Res (this issue)

6. Bonner IJ, Muth DJ Jr., Koch JB, Karlen DL (2014) Modeled impacts of cover crops and vegetative barriers on corn stover availability and soil quality. Bioenergy Res 7(2). doi:10.1007/s12155-014-9423-y

7. Archer DW, Karlen DL, Liebig MA (2014) Crop residue harvest economics: An Iowa and North Dakota case study. Bioenergy Res 7(2). doi:10.1007/s12155-014-9428-6

8. Johnson JMF, Varvel GE, Stott DE, Osborne SL, Novak JM, Karlen DL, Lamb JA, Baker JM (2014) Crop residue mass needed to maintain soil organic carbon levels: Can it be determined? Bioenergy Res 7(2). doi:10.1007/s12155-013-9402-8

9. Osborne SL, Johnson JMF, Jin VL, Varvel GE, Schumacher TE (2014) The impact of corn residue removal on soil aggregates and particulate organic matter. Bioenergy Res 7(2). doi:10.1007/s12155014-9413-0

10. Benjamin, JG, Karlen DL (2014) Techniques for quantifying potential soil compaction consequences of crop residue removal. Bioenergy Res 7(2). doi:10.1007/s12155-013-9400-x

11. Lehman M, Ducey T, Jin V (2014) Soil microbial community response to corn stover harvesting used rain-fed, no-till conditions at multiple U.S. locations. Bioenergy Res 7(2). doi:10.1007/s12155-014-9417-9

12. Jin VL, Baker JM, Johnson JMF, Karlen DL, Lehman RM, Osborne SL, Sauer TJ, Stott DE, Varvel GE, Venterea RT (2014) Soil greenhouse gas emissions in response to corn stover removal and dtillage management across the U.S. corn belt. Bioenergy Res 7(2). doi:10. 1007/s12155-014-9421-0

13. Baker JM, Fasshinder J, Sauer TJ, Lamb JA (2014) The impact of corn stover removal on $\mathrm{N} 2 \mathrm{O}$ emission and soil respiration: An investigation with automated chambers. Bioenergy Res 7(2). doi: 10.1007/s12155-014-9412-1

14. Campbell EE, Johnson JMF, Jin VL, Varavel GE, Adler PR, Paustian $\mathrm{K}$ (2014) Assessing the soil carbon, biomass production, and nitrous oxide emission impact of corn stover management for bioenergy feedstock production using DAYCENT. Bioenergy Res 7(2). doi: 10.1007/s12155-014-9414-Z

15. Mourtzinis S, Canatrell KB, Arriaga F, Novak JM, Frederick JR, Karlen DL (2014) Distdribution of structural carbohydrates in corn plants across the Southeastern U.S. Bioenergy Res 7(2). doi:10.1007/ s12155-014-9429-5

16. Cantrell, KB, Novak JM, Frederick JR, Karlen DL, Watts DW (2014) Influence of corn residue harvest management on grain, stover, and energy yields on Coastal Plain toposequential soils. (Bioenergy Res (this issue) 